\title{
PREDLOG METEOROLOŠKE STANICE NAMENJENE UPOTREBI U POLJOPRIVREDNOJ PROIZVODNJI
}

\author{
Majid Hamid Abdullah ${ }^{1, *}$, \\ Žaklina Spalević', \\ Miloš llić2 \\ Petar Spalević2, \\ Nenad Stanojević ${ }^{2}$
}

\author{
1 Univerzitet Singidunum, \\ Beograd, Srbija \\ ${ }^{2}$ Fakultet Tehničkih nauka, \\ Univerzitet u Prištini sa privremenim sedištem \\ u Kosovskoj Mitrovici, Srbija
}

\begin{abstract}
Rezime:
Aktivnosti vezane za poljoprivrednu proizvodnju uslovljene su meteorološkim uslovima. Praćenje promena meteoroloških uslova kao jednog od preduslova u procesu donošenja odluka u okviru poljoprivredne proizvodnje može predstavljati kompleksan problem. Složenost ovog problema nastaje zbog nedostupnosti meteoroloških stanica poljoprivrednim proizvođačima. Rešenje problema ogleda se u kreiranju i korišćenju meteorološke stanice posebno dizajnirane za potrebe praćenja meteoroloških i prostorno vremenskih parametara na proizvodnim poljoprivrednim površinama. Predloženi model meteorološke stanice predstavlja rešenje koje uključuje dovoljan broj senzora za prikupljanje meteoroloških i prostorno vremenskih parametara. $\mathrm{U}$ isto vreme realizacija ovakvog rešenja karakteriše se ekonomskim izdacima nekoliko puta manjim od komercijalnih rešenja meteoroloških stanica dostupnih na tržištu.
\end{abstract}

Ključne reči:

Raspberry Pi, DS18B20, ZigBee XBee, SIM900 GSM/GPRS.

\section{UVOD}

Precizna poljoprivreda u osnovi se zasniva na praćenju trenutnih meteoroloških parametara i kreiranju što je moguće preciznije predikcije zasnovane na meteorološkim parametrima. U zavisnosti od meteoroloških uslova mogu se razlikovati dnevne aktivnosti kao i aktivnosti koje će se obavljati u nekom budućem periodu. Posmatrano iz ugla meteoroloških promena praćenje meteorloških uslova nastaje kao spoj primene nauke i tehnologije u cilju predikcije stanja atmosfere za datu oblast posmatranja [1]. Korišćenjem sistema za praćenje meteoroloških promena agronomi kao i poljoprivredni proizvođači mogu prikupiti informacije o različitim vremenskim parametrima kao što su: temperatura vazduha, vlažnost vazduha, brzina i smer vetra, količina padavina, itd. Pored pomenutih meteorloških parametara meteorološke stanice mogu vršiti i merenje specifičnih parametara kao što su vlažnost zemljišta, vlažnost lista biljke, itd. $\mathrm{Na}$ osnovu trenutnih merenja meteoroloških parametara kao i meranja vršenih tokom dužeg vremenskog perioda u prošlosti, mogu se kreirati precizni modeli izvršenja poljoprivrednih aktivnosti. 
Različiti tipovi meteoroloških stanica, posebno automatizovanih, koriste se za prikupljanje potrebnih podataka. Kada se govori o opremljenosti meteorološke stanice u cilju adekvatnog korišćenja svaka od meteoroloških stanica trebalo bi da bude opremljenja odgovarajućom grupom senzora. Skup senzora kojima će konkretna meteorloška stanica biti opremljena zavisi od unapred definisane namene.

Prostorno vremenski parametri pored meteoroloških parametara čine još jednu od bitnijih komponenti u radu meteorloške stanice. Značajnost prostorno vremenskih parametara posebno se ogleda ukoliko na određenom lokalitetu postoji sistem od više meteoroloških stanica. Ovakav sistem u najvećem broju slučajeva povezan je sa jednom jedinstvenom baznom stanicom do koje se vrši slanje izmerenih vrednosti meteoroloških parametara. Prostorno vremenska komponenta svakog od paketa podataka uvodi mogućnost klasterizovanja podataka na osnovu lokacije na kojoj su izmerene date vrednosti kao i na osnovu vremena kada je merenje izvršeno. Na ovakav način ukoliko se na različitim lokalitetima uzgajaju različite kulture omogućeno je preciznije sagledavanje meteorološke situacije posmatranjem isključivo meteoroloških merenja za dati lokalitet.

Izmerene vrednosti meteoroloških i prostorno vremenskih parametara na nekom udaljenom lokalitetu ne znače puno ukoliko se očitavanje istih mora obaviti na samom lokalitetu. Kako se meteorološke stanice namenjene upotrebi u poljoprivredi nalaze na proizvodnim površinama koje su udaljene od mesta stanovanja lica koje prati promenu parametara iste bi trebalo da poseduju mogućnost slanja podataka do bazne stanice. Praktično pored opremljenosti meteorološke stanice potrebnim senzorima ona mora biti opremljena i odgovarajućim hardverom kojim će omogućiti slanje podataka. Uspešno slanje paketa podataka ne sme biti uslovljeno rastojanjem između meteorološke i bazne stanice. Kako je realizacija meteorološke stanice u velikoj meri uslovljena i cenom komponenti dostupnih na tržištu, kada se govori o komponentama koje bi se mogle iskoristiti u cilju realizacije sopstvene meteorološke stanice gotovo sve komponente je moguće kupiti na slobodnom tržištu. $\mathrm{Na}$ ovakav način kreiranje sopstvene meteorološke stanice može biti znatno povoljnije od kupovine komercijale stanice nekog od poznatih proizvođača.

Cilj ovog rada orijentisan je ka kreiranju modela meteorološke stanice namenjene upotrebi u poljoprivrednoj proizvodnji. Rad je organizovan na sledeći način. U drugom delu zada opisane su odabrane meteorološke i prostorno vremenske komponente meteorološke stanice. U trećem delu zada dat je opis komponenti za prenos paketa podataka. Dok poslednja dva poglavlja predstavljaju zaključak i popis literature.

\section{KOMPONENTE METEOROLOŠKE STANICE}

Predloženi model meteorološke stanice kreiran je na bazi opreme dostupne na tržištu sa osvrtom na praktičnu efikasnost i ekonomske izdatke. U cilju odabira najadekvatnijih komponenti izvršena je analiza komponenti dostupnih na tržištu. Analizirane su karakteristike komponenti propisane od strane proizvođača, kao i tržišna cena istih.

\section{Računar meteorološke stanice}

Jednu od osnovnih komponentni meteorološke stanice zauzima Raspberry Pi 3 Model B računar koji upravlja radom svih senzora. Raspberry Pi je računar malih dimenzija sa operativnim sistemom na Micro SD memorijskoj kartici. Pored malih dimenzija i niske cene, karakteristike ovog računara ne zaostaju za karakteristikama personalnih računara. Karakteristično za treću generaciju ovog računara je i to da radi na GNU/Linux platformi kao i na Windows 10 platformi [2]. Na ovakav način daje dobru osnovu za eventualno proširenje i komunikaciju sa drugim uređajima. Rad ovog računara zasnovan je na Broadcom BCM2837B0, ARM CortexA53 64-bitnom procesoru brzine od 1.4GHz. Ovaj procesor zasniva se na moguća četiri jezgra, pri čemu svako od jezgara sadrži sopstvenu L1 memoriju. Pored L1 memorije procesor poseduje i jednu deljivu L2 memoriju. Povezivanje senzora sa ovim računarom obavlja se preko ulazno izlaznih pinova opšte namene (eng. General Purpose Input/Output pins - GPIO) koji se nalaze na ploči računara i kojih ima ukupno četrdeset. GPIO pinovi mogu se konfigurisati kao ulazni pinovi opšte namene, kao izlazni pinovi opšte namene ili kao jedna od šest alterantivnih specijalnih namena. Svih četrdeset GPIO pinova je podeljenje u tri banke u skladu sa pomenutim procesorom. Svaka od banaka ima svoj VDD ulazni pin. Takođe svaka od banaka se napaja sa 3,3V. Od ukupnog broja pinova dva pina pružaju napajanje od $5 \mathrm{~V}$, dok takođe dva pina pružaju napajanje od 3,3V. U isto vreme na ploči se nalazi veći broj pinova uzemljenja koji nisu konfigurisani. Sve ostali pinovi su kao što je navedeno pinovi opšte namene čiji je izlaz postavljen na 3,3V dok je ulaz tolerantan do 3,3V. Ovo praktično znači da se pinovi koji su dizajnirani kao izlazni mogu postaviti na napajanje do 3,3V ili manje. 
Temperaturni senzor

Poznato je da je jedna od karakteristika temprature vazduha njena oscilacija tokom data. Kako su pojedini poljoprivredni procesi zavisni od dnevnih temperatura veoma je važan i odabir odgovarajućeg temperaturnog senzora. Analiza temperaturnih senzora na osnovu karakteristika datih od strane proizvođača prikazana je u tabeli 1 .
Za merenje spoljašnje temperature iz opisane grupe senzora odabran je DS18B20 temperaturni senzor. Ovo je temperaturni senzor koji dolazi postavljen na kraju kabla dužine $91 \mathrm{sm}$ i prečnika $4 \mathrm{~mm}$. Dužina kabla omogućava montažu senzora na određenoj udaljenosti od Raspberry Pi uređaja. Takođe sami senzor je vodootporan. Zbog načina povezivanja kao i svoje vodootpornosti savršen je za primenu u spoljašnjim uslovima.

Tabela 1. Poređenje temperaturnih senzora

\begin{tabular}{|c|c|c|c|c|}
\hline Oznaka senzora & $\begin{array}{l}\text { Merni opseg } \\
{\left[{ }^{\circ} \mathrm{C}\right]}\end{array}$ & $\begin{array}{l}\text { Propisana tačnost } \\
{\left[{ }^{\circ} \mathrm{C}\right]}\end{array}$ & $\begin{array}{c}\text { Napajanje } \\
{[\text { V] }}\end{array}$ & $\begin{array}{c}\text { Približna cena } \\
\text { [din] }\end{array}$ \\
\hline DS18B20 & -55 do +125 & $\pm 0,5$ & $3,0-5,5$ & 1200,00 \\
\hline DS18B20-H & -55 do +125 & $\pm 0,5$ & $3,0-5,5$ & 1800,00 \\
\hline DS1818-10 & -40 do +85 & $\pm 8,5$ & 3,3 & 240,00 \\
\hline DS1822 & -55 do +125 & $\pm 2,0$ & $3,3-5,5$ & 780,00 \\
\hline DS18B20Z & -55 do +125 & $\pm 0,5$ & $3,0-5,5$ & 768,00 \\
\hline
\end{tabular}

Senzor za merenje temperature i relativne vlažnosti vazduha

Relativna vlažnost vazduha još jedan je od meteoroloških parametara za čije praćenje je potrebno odabrati odgovarajući senzor. Senzori za merenje relativne vlažnosti vazduha najčešće se na tržištu nalaze u kombinaciji sa temperaturnim senzorima. Naime u okviru jednog senzora vrši se kombinovano merenje dva parametra. Upravo iz ovog razloga vršeno je poređene performansi najzastupljenijih kombinovanih senzora za merenje temperature i relativne vlažnosti vazduha. Rezultati analize poređenja dostupnih senzora prikazani su u tabeli 2 .

Pored prikazanih razlika između navedenih senzora koje se odnose na merne opsege vlažnosti vazduha i temperature, kao i propisane tačnosti prilikom merenja još jedna od karakteristika kao što je bio slučaj sa temperaturnim senzorom jeste otpornost na vremenske uslove. Ukoliko se posmatra uticaj spoljašnih uslova na rad senzora u grupu senzora otpornih na vremenske uslove mogu se uvrstiti HIH6030 i senzori koji pripadaju seriji
SHT1x. Pored sličnih tehničkih karakteristika kojima se odlikuju, kao i činjenice da su oba senzora otporna na vremenske uslove, činjenica koja ih razdvaja jeste cena. SHT1x senzori kao što se može videti iz tabele 2 daleko su skuplji nego što je to slučaj sa HIH6030 senzorom. Međutim detaljnijim poređenjem i istraživanjem utvrđeno je da HIH6030 senzor nije dovoljno otporan na vremenske ulove, tačnije pravilan rad ovog senzora može ometati prašina i kondenzacija.

Dodatna ulaganja u zaštitu ovog senzora od vremenskih uslova, izvedena tako da ne utiču na njegove performanse skoro da bi izjednačila cenu ovog senzora sa cenom senzora iz serije SHTx. Takođe činjenica da senzori serije SHTx dolaze unapred zaštićeni sa mogućnošću povezivanja putem kabla otvara dodatne pogodnosti u njihovom korišćenju. Kako se u ovoj seriji nalaze tri po karakteristikama različita senzora izvršen je odabir jednog. Prema tehničkim karakteristikama SHT15 senzor odlikuje se najpreciznijim merenjima. Pritom opeseg merenja, napajanje i cena ovog senzora su istovetni kao što je to slučaj sa ostalim senzorima ove serije. 
Tabela 2. Poređenje senzora za merenje temperature i relativne vlažnosti vazduha

\begin{tabular}{|c|c|c|c|c|c|c|}
\hline \multirow[b]{2}{*}{ 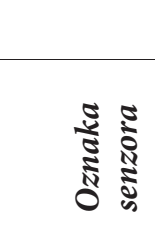 } & \multicolumn{2}{|c|}{ Relativna vlažnost } & \multicolumn{2}{|c|}{ Temperatura } & \multirow[b]{2}{*}{$\frac{\sqrt{2}}{3}$} & \multirow[b]{2}{*}{ 谞 } \\
\hline & 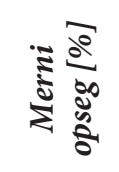 & 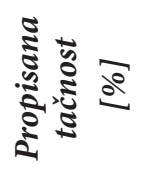 & 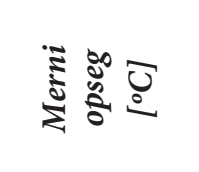 & 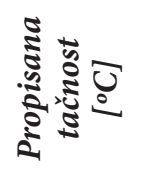 & & \\
\hline SHT15 & $0-100$ & \pm 2.0 & -40 do +120 & $\pm 0,3$ & $2,4-5,0$ & 6000,00 \\
\hline HIH6030 & $0-100$ & $\pm 4,5$ & -40 do +100 & $\pm 0,5$ & $2,3-5,5$ & 800,00 \\
\hline DHT22 & $0-100$ & $\pm 2-5$ & -40 do +80 & $\pm 0,5$ & $3,0-5,0$ & 1800,00 \\
\hline SHT10 & $0-100$ & $\pm 4,5$ & -40 do +120 & $\pm 0,5$ & $2,4-5,0$ & 6000,00 \\
\hline SHT11 & $0-100$ & \pm 3.0 & -40 do +120 & $\pm 0,4$ & $2,4-5,0$ & 6000,00 \\
\hline AM2315 & $0-100$ & $\pm 2,0$ & -20 do +80 & \pm 0.1 & $3,5-5,5$ & 3600,00 \\
\hline DHT11 & $20-80$ & $\pm 5,0$ & 0 do +50 & $\pm 2,0$ & $3,0-5,0$ & 600,00 \\
\hline
\end{tabular}

\section{Senzor za merenje količine padavina}

Svi uređaji za merenje količine padavina dostupni na tržištu rade na istom principu pa samim tim nije bilo potrebe za nekim detaljnijim analizama i poređenjima. Odabrani uređaj za merenje količine padavina u osnovi je posuda koja se sama prazni. Ovaj uređaj napravljen je kao levkasti sud u kome se sakuplja kišnica i kanališe do posuda za sakupljanje. Kada se sakupi dovoljna količina vode dolazi do prevrtanja posude i njenog pražnjenja. $\mathrm{U}$ isto vreme posuda na suprotnoj strani se pozicionira u položaj za punjenje. Količina vode koja je potrebna da bi izvršila prevrtanje posude i njeno pražnjenje iznosi $0,2794 \mathrm{~mm}$ kiše. Dati podatak pokazuje da je uređaj projektovan tako da evidentira i male količine padavina. Sa svakim pražnjenjem posude vrši se i zatvaranje električnog kola pomuću prekidača što se evidentira pomoću digitalnog brojača ili prekidom mikrokontrolera. Praktično svako pražnjenje uzrokuje inkrementiranje brojača. Ukupna količina padavina za dati period izračunava se množenjem vrednosti brojača i količine vode potrebne za iniciranje pražnjenja. Unutar grebena između pomenute dve posude nalaizi se mali cilindrični magnet koji pokazuje prema zadnjem zidu. U samom zadnjem zidu nalazi se pomenuti prekidač. Praktično kada se jedna od posuda prevrne magnet prolazi prekidač i uzrokuje njegovo trenutno zatvaranje. Ukoliko je prekidač povezan sa GPIO pionom na mikrokontroleru njegovo zataranje će generisati niski signal koji se može otkriti i evidentirati kao inkrement za jedan. Ovakav uređaj za merenje količine padavina može se povezati na dva načina. Uobičajeno dolazi opremljen RJ11 priključ- kom iako koristi samo dve žice, jednu crvenu i jednu zelenu. Praktično ukoliko na mikrokontroleru postoji mogućnost povezivanja preko RJ11 utikača isti se može iskoristiti. Sa druge strane ukoliko ovakva mogućnost ne postoji može se povezati preko ulazno izlaznih pinova opšte namene uklanjanjem utikača i povezivanjem pomoći žica. Prednost ovog uređaja je rad bez spoljašnjeg napajanja. Praktično rad uređaja je zasnovan na mehaničkim principima pa samim tim ne zahteva bilo spoljašnje napajanje bilo napajanje preko mikrokontrolera.

\section{Senzor za merenje brzine i smera vetra}

Senzor za merenje brzine vetra tradicionalno se naziva anemometar i sastoji se od nekoliko polulopti koje pod uticajem vetra rotiraju na zajedničkoj osovini. U najvećem broju slučajeva najprostiji mehanizam rada zasniva se na mehaničkom delovanju magneta na prekidač kao što je to bio slučaj sa senzorom za količinu padavina. $U$ tabeli 3 dato je poređenje različitih anemometra dostupnih na tržištu.

Kao što se može videti iz date tabele osnovna razlika između navedenih anemometra zasniva se na preciznosti merenja, izlaznom signalu kao i na osetljivosti samog anemometra. Pod osetljivošću anemometra smatra se minimalna jačina vetra koja je potrebna da pokrene rotaciju i samim tim inicira merenje. Za potrebe realizacije meteorološke stanice odabran je Adafruit1733 anemometar. Značajno za odabrani anemometar s obzirom da je namenjen primeni na otvorenom jeste da je otporan je na uticaj vremenskih uslova, koroziju kao i uticaj vlage. Materijali od kojih je napravljen obezbeđuju 
trajnost uređaja kao i tačnost prilikom merenja brzine vetra. Tačnost ovog anemometra kao što se može videti veoma je zadovoljavajuća i iznosi $\pm 1 \mathrm{~m} / \mathrm{s}$. Brzina vetra potrebna za pokretanje merenja kod ovog tipa anemometra obezbeđuje merenje vetra gotovo najmanje jačine. Maksimalna brzina vetra koju dati anemometar može evidentirati daleko je viša od brzine vetra potrebne za istraživanja u oblasti predikcije i iznosi $70 \mathrm{~m} / \mathrm{s}$. Takođe za pomenuti senzor definisano je i ograničenje u vidu maksimalne spoljašnje temperature na kojoj anemometar može raditi i koja iznosi od $-40^{\circ} \mathrm{C}$ do $+80^{\circ} \mathrm{C}$. Odabrani anemometar dolazi sa kablom za napajanje i prenos očitanih vrednosti dužine $3 \mathrm{~m}$, što omogućava njegovo pozicioniranje na vrh nosača.

Tabela 3. Poređenje senzora za merenje brzine i smera vetra

\begin{tabular}{lccccc}
\hline \multicolumn{1}{c}{ Ознака } & $\begin{array}{c}\text { Стартна } \\
\text { брзина } \\
{[\mathbf{m} / \mathbf{s}]}\end{array}$ & $\begin{array}{c}\text { Мерни опсег } \\
{[\mathbf{m} / \mathbf{s}]}\end{array}$ & $\begin{array}{c}\text { Тачност } \\
{[\mathbf{m} / \mathbf{s}]}\end{array}$ & $\begin{array}{c}\text { Излазни } \\
\text { сигнал } \\
{[\mathbf{V}]}\end{array}$ & $\begin{array}{c}\text { Цена } \\
{[\mathbf{d i n}]}\end{array}$ \\
\hline Adafruit1 733 & 0,2 & $0,5-70$ & \pm 1 & $0,4-2$ & 5500,00 \\
\hline BAN 1093558 & $0,2-0,4$ & $0,2-32,4$ & \pm 1 & $0,4-2$ & 6200,00 \\
\hline JL-FS2 & $0,4-0,8$ & $0,0-30$ & \pm 1 & $0-5$ & 8000,00 \\
\hline Met One 010C & 0,22 & $0,0-50$ & $\pm 0,07$ & 11 & 29000,00 \\
\hline Met One 013 & 0,45 & $0,0-67$ & $\pm 0,11$ & 11 & 20000,00 \\
\hline
\end{tabular}

Pokazivač smera vetra još jedan je od senzora koji spadaju u grupu meteoroloških senzora. Posmatrano iz domena funkcionalnosti može se smatrati da je ovaj senzor možda i najsloženiji od svih meteoroloških senzora. Ukoliko se posmatra mehaničko rešenje ovog senzora pri čemu bi isti radio bez dodatnog ulaznog napajanja pokazivač smera vetra sastojao bi se od osam preklopnika od kojih je svaki povezan sa različitim otpornikom. Svaki od osam otpornika ima različitu otpornost, što obezbeđuje šesnaest različitih mogućih kombinacija otpornosti. Magnet u okviru pokazivača pravca vetra prilikom rada može zatvoriti dva preklopnika od jednom što omogućava pokazivanje do 16 različitih pozicija. Ovo se praktično dešava u momentima kada je pozicioniran na pola puta između dva preklopnika. Kako bi se očitao pravac vetra sa pokazivača pravca vetra potrebno je izmerenu otpornost dobijenu sa senzora konvertovati u analognu vrednost. Umesto direktnog merenja otpornosti jednostavniji pristup je merenje napona na pokazivaču pravca koji varira u odnosu na to koja kombinacija otpornika je trenutno uključena u kolo pomoću preklopnika. Ovo praktično znači da se vrši merenje analogne vrednosti. Praktično pokazivač pravca će konstantno kao izlaznu vrednost davati opseg napona. Na ovakav način kreira se izlazni napon koji se može izmeriti pomoću A/D konvertora. Potreba za korišćenjem dodatnog A/D konvertora proizilazi iz činjenice da Raspberry Pi poseduje samo digitalne ulaze. Jedan od popularnijih
A/D konvertora je MCP3008. Integrisano kolo ovog konvertora sastoji se od 16 pinova sa 8 analognih ulaza koji se mogu koristiti kao kolo za konverziju. Takođe poseduje 10-bitni ADC što praktično znači da ima 1024 mogućih izlaznih vrednosti za referentni napon od $5 \mathrm{~V}$. Najmanja vrednost promene napona koju ovaj konverter može detektovati iznosi 5V/1024=4.88 mV.

\section{Senzor za merenje vlažnosti zemljišta}

Uloga senzora za merenje vlažnosti zemljišta ogleda se konstantnom merenju količne vode u zemljištu u cilju održavanja odgovarajuće vlažnosti potrebne za pravilan uzgoj biljaka. Senzor za merenje vlažnosti zemljišta postavlja se ispod nivoa zemlje na unapred definisanoj dubini. Dubina postavljanja senzora zavisi od biljne vrste koja se gaji na datoj površini. Princip rada senzora za merenje vlažnosti zemljišta dostupnih na tržištu zasniva se na dve sonde. Kroz sonde se u zemlju prenosi električna energija, nakon čega se na osnovu izmerene otpornosti izračunava nivo vlage. Veća vlažnost zemljišta omogućava bolju provodnost, a samim tim i manju otpornost, dok suva zemlja slabo provodi električnu energiju zbog većeg otpora. Senzori za merenje vlažnosti zemljišta dostupni na tršištu istovetnih su karakteristika. Presudni parametar u odabiru odgovarajućeg bila je cena. Za potrebe realizacije modela meteorološke stanice odabran je Octopus senzor za merenje 
vlažnosti zemljišta. Ovaj senzor napaja se konstantnim napajanjm od 3,3V do 5V što odgovara potrebama realizacije meteorološke stanice s obzirom na činjenicu da se napajanje može vrštiti direktno sa Raspberry Pi uređaja ili sa spoljašnjeg napajanja. Izlazni signal kojim se prenosi izmerena vrednost je u granicama od $0-4,2 \mathrm{~V}$ što takođe odgovara potrebama realizacije modela.

\section{Senzor za merenje vlažnosti lista}

Pojava vlažnosti lista biljke izučava se decenijama unazad posebno u oblasti fitopatologije i poljoprviredne meteorologije. Direktno merenje vlažnosti lista je veoma problematično, jer je veoma teško povezati senzor na list biljke. Sama pozicija lista, njegova izloženost suncu kao i zdravstveno stanje stalno su promenljivi. Kako bi se izbegli ovi problemi razvijeni su senzori koji vrše procenu moguće vlažnosti listova u čijoj se blizini nalaze. Princip rada ovih senzora zasniva se na merenju dialektrične konstante gornje površine senzora. Ovakav senzor može detektovati prisustno najmanje količine vode ili leda na svojoj površini. Kako se na tržištu mogu naći različiti senzori za merenje vlažnosti lista u tabeli 4 su prikazani analizom obuhvaćeni senzori.

Iz grupe analiziranih senzora prikazanih u tabeli 4 na osnovu potrebni karakteristika odabran je Decagon senzor. Princip rada ovog senzora zasniva se na detekciji promene električne otpornosti između pozlaćenih elemenata mreže od koje je napravljen. Praktično kao i ostali senzori ove grupe decagon senzor merei dielektričnu konstantu u zoni približno $1 \mathrm{~cm}$ iznad površine senzora. Poznato je da je dielektrična konstanta vode 80 , leda 5 , što je znatno veće od dielektrične konstante vazduha koja iznosi 1.

Tabela 4. Poređenje senzora za merenje vlažnosti lista

\begin{tabular}{lcccc}
\hline \multicolumn{1}{c}{ Oznaka } & $\begin{array}{c}\text { Napajanje } \\
{[\mathbf{V}]}\end{array}$ & Izlazni napon $[\mathbf{m V}]$ & $\begin{array}{c}\text { Radna temperatura } \\
{\left[{ }^{\circ} \mathbf{C}\right]}\end{array}$ & Dužina kabla $[\mathbf{m}]$ \\
\hline Decagon & $2,5-5$ & $320-1000$ & -20 do +60 & 5 \\
\hline PHYTOS 31 & $2,5-5$ & $320-1250$ & -40 do +50 & 5 \\
\hline Vantage Pro & 3,0 & $2500-3000$ & -20 do +60 & 5 \\
\hline ADCON Wet & $2,2-12,0$ & $0-2500$ & -20 do +60 & 3 \\
\hline 260-RK300-04 & $12,0-24,0$ & $0-5000$ & -40 do +70 & 3 \\
\hline
\end{tabular}

Senzor emituje signal u mV koji je proporcionalan dielektričnoj vrednosti u zoni merenja, i samim tim proporcionalan količini vode ili lega na površini senzora. Debljina fiberglasa od koga je napravljen ovaj senzor iznosi $0,65 \mathrm{~mm}$ što je približno debljini lista biljke. Ukoliko je toplota lista procenjena na $1425 \mathrm{~J} \mathrm{~m}^{-2} \mathrm{~K}^{-1}$, a njegova debljina na $0.4 \mathrm{~mm}$ onda je kapacitet toplote senzora $\mathrm{s}$ obzirom na njegovu debljinu $1480 \mathrm{~J} \mathrm{~m}^{-2} \mathrm{~K}^{-1}$. Upravo iz ovog razloga kondenzacija vlage na senzoru kao i njeno isparenje se odigrava istom brzinom kao na normalnom lišću. Vremenski period jednog očitavanja iznosi 10ms. Ovaj senzor može se montirati na samoj meteorološkoj stanici ili u okviru biljke među njenim lišćem. Ukoliko se senzor montira na biljci dužina kabla može se povećati u odnosu na inicijalnih $5 \mathrm{~m}$ bez uticaja na samo merenje i prenos očitanih vrednosti. Proces povezivanja senzora može se realizovati na dva načina. Prvi od načina je korišćenje Decagon data logera, dok je drugi od načina korišćenje nekog drugog uređaja u zamenu za data loger. Kako se u slučaju predloženog modela meteorološke stanice ne koristi Decagon data loger potrebno je prekinuti originalni priključak i povezivanje uraditi pomoću žica koje se nalaze u samom kablu.

Komponente za prikupljanje prostorno vremenskih parametara

Prostorno vremenska komponenta svakog od paketa podata poslatih sa metorološke stanice do bazne stanice kao što je ranije navedeno značajna je u domenu postojanja sistema meteoroloških stanica povezanih na jednu baznu stanicu. Pritom ove dve komonente se mogu razdvojiti na prostornu i vremensku komponentu. Bez obzira da li postoji jedna ili više meteoroloških stanica vremenska komponenta značajna je zbog evidentiranja vremena očitavanja parametra, kao i praćenja promena meteorloških vrednosti tokom perioda trajanja dana. 
Prostorna komponenta sa druge strane nije potrebna ukoliko postoji samo jedna meteorološka stanica i ukoliko je ona uvek na istoj lokaciji. Prostorno vremenska komponenta je uključena u okviru modela meteorološke stance upravo zbog postojanja potrebe za realizacijom sistema koji sadrži više od jedne meteorološke stanice. Za potrebe određivanja prostorno vremenskih koordinata u model meteorološke stanice uveden je GPS modul. Zbog postojanja većeg broja hardverskih rešenja GPS modula koja se mogu iskoristiti i povezati sa Raspberry Pi računarom izvršena je analiza u cilju odabira najedakvatnijeg. Karakteristike poređenih modela date su u tabeli 5.

Tabela 5. Poređenje karakteristika prostorno vremenskih komponenti

\begin{tabular}{|c|c|c|c|c|c|c|}
\hline 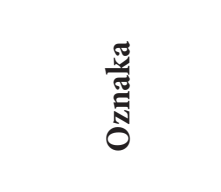 & 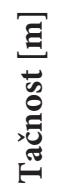 & 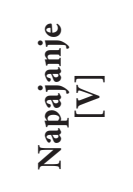 & 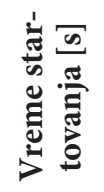 & 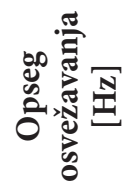 & 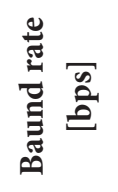 & 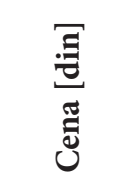 \\
\hline $\begin{array}{l}\text { Adafruit } \\
\text { PA6H1F1702 }\end{array}$ & 3 & $3,0-5,5$ & 34 & $1-10$ & 9600 & 5000,00 \\
\hline $\begin{array}{l}\text { MediaTek } \\
\text { GPS-2261 }\end{array}$ & 3 & 5,0 & 36 & $1-10$ & 9600 & 3000,00 \\
\hline $\begin{array}{l}\text { GPS-NEO- } \\
6 \mathrm{M}-001\end{array}$ & 3 & $3,0-5,0$ & 36 & $1-10$ & 38400 & 2000,00 \\
\hline PA6C1V1438 & 3 & 5,00 & 36 & $1-10$ & 9600 & 1800,00 \\
\hline
\end{tabular}

Za potrebe realizacije meteorološke stanice odabran je Adafruit PA6H1F1702 GPS modul. Hardversko rešenje ovog modula izgrađeno je oko MTK3339 chipset-a, koji predstavlja GPS modul visokog kvaliteta, koji može pratiti do 22 satelita kroz 66 kanala. Ovaj GPS modul ima visoko osetljivi resiver od $-165 \mathrm{dBm}$ prilikom praćenja, kao i ugrađenu antenu. Odlikuje se takođe malom potrošnjom energije do $20 \mathrm{~mA}$ prilikom ogređivanja lokacije, kao i modom mirovanja koji se odlikuje još manjom upotrebom energije. U verziji 3 ovog modula moguće je povezivanje spoljašnje antene koja omogućava preciznije određivanje pozicije.

\section{KOMPONENTE ZA PRENOS}

Udaljeni pristup i slanje podataka od meteorološke stanice do bazne stanice predstavlja dodatni problem koji zahteva posebnu analizu u cilju kreiranja adekvatnog rešenja. Kao jedno od potencijalnih rešenja nameće se korišćenje bežičnih senzornih mreža u vidu prenosa podataka putem radio frekvencije, ili prenosa podataka putem GSM mreže. Primena jedne ili druge tehnologije kao i eventualna primena hibridnog rešenja koje bi obuhvatilo korišćenje obeju tehnologija uslovljena je rasporedom meteoroloških stanica, njihovom međusobnom udaljenošću kao i konfiguracijom terena na kojem su meteorološke stanice postavljene.

Prenos parametara radio frekvencijom

Proces prenosa parametara moguće je realizovati primenom hardverskih rešenja koja će omogućiti korišćenje radio frekvencije. Teorijski posmatrano u okviru već pomenutih hardverskih uređaja na meteorološkoj stanici potrebno je dodati radiofrekventni primopredajnik. Bazna stanica sa druge strane takođe mora da poseduje radiofrekventni primopredajnik. Ukoliko se radi o sistemu u kome se nalazi veći broj meteoroloških stanica u zavisnosti od primenjenog hardverskog rešenja meteorološke stanice i bazna stanica moraju se postaviti tako da zadovoljavaju određenu topologiju [3]. Sama topologija uslovljena je konfiguracijom terena kao i maksimalnom linijom vidljivosti između bazne stanice i meteoroloških stanica. Primenjeno na modelom opisanu meteorološku stanicu odabir hardverskog rešenja za radio primopredajnik mora biti takav da koristi isto napajanje kao i Raspberry Pi računar. Poređenje radio frekvetnih modula dostupnih na tržištu i adevatnih za primenu u slučaju ovako kreirane meteorološke stanice dato je u tabeli 6 . 
Tabela 6. Poređenje RF modula XBee familije

\begin{tabular}{lccc}
\hline \multicolumn{1}{c}{ Naziv familije } & Frekvenca & Način sklapanja & Protokol \\
\hline XBee ZigBee & $2.4 \mathrm{GHz}$ & TH/SMT & ZigBee \\
\hline XBee 802.15 .4 & $2.4 \mathrm{GHz}$ & Through-Hole & 802.15 .4 \\
\hline XBee S2C 802.15.4 & $2.4 \mathrm{GHz}, 900 \mathrm{MHz}$ & TH, SMT & 802.15 .4 \\
\hline XBee DigiMesh 2.4 & $2.4 \mathrm{GHZ}$ & Through-Hole & DigiMesh \\
\hline
\end{tabular}

Pored opisanih karakteristika odabrano hardversko rešenja mora da poseduje tehničke mogućnosti povezivanja sa Raspberry Pi računarem u cilju adekvatnog slanja i prijema podataka i upravljačkih signala. Teorijski posmatrano praktična realizacija ogleda se u nabavci dva istovetna radio frekvetna modula, od kojih će jedan biti postavljen na meteorološkoj stanici, dok će drugi biti postavljen u okviru bazne stanic. Takođe u zavisnosti od konfiguracije terena i maksimalne propagacije signala u okviru linije vidljivosti postoji i mogućnost uvođenja dodatnih pojačavača snage signala. Pojačavači snage signala primenjuju se ukoliko je potrebno signal preneti na veću razdaljinu od maksimalne razdaljine koju osnovni predajnik može preneti. Takođe pojačavači se koriste u slučajevima kada je teren brdovit ili kada postoje prepreke koje utiču na propagaciju samog signala. Praktično pojačavač pojačava oslabljenu snagu signala i potrebno ga je postaviti na mestu do koga signal emitovan sa predajnika dolazi oslabljen. Kao što se može videti u tabeli 6 različite familije radio frekventnih modula pogodnih za realizaciju slanja podataka sa meteorološke stanice dostupne su od strane kompanije Digi International' ${ }^{1}$ Svaka od familija karakteriše se različitim funkcionalnostima uređaja koje obuhvata.

Nakon eliminacije određenih kategorija RF modula, a na osnovu tehničkih karakteristika preostalih familija i kategorija RF modula za potrebe realizacije prenosa podataka od modelom opisane meteorološke stanice do bazne stanice odabrana je Digi XBee S2C 802.15.4 kategorija koja pripada XBee S2C 802.15.4 familiji RF modula.

\section{Prenos parametara GSM/GPRS mrežom}

Prenos parametara sa jednog mobilnog uređaja do drugog mobilnog uređaja može se obaviti korišćenjem GSM (eng. Global System for Mobile Communication) ili GPRS (eng. General Packet Radio Service) mreže. Generalno posmatrano mobilna mreža slična je fiksnoj telefoniji. Osnovna razlika ogleda se u mogućnostima

1 Digi International, https://www.digi.com/ neograničene mobilnosti pretplatnika koja je ostvarena korišćenjem bežičnog interfejsa sa sistemom. GSM je praktično evropski standard za digitalne mobilne sisteme zasnovan na korišćenju tri različita frekventna opsega: $900 \mathrm{MHz}, 1800 \mathrm{MHz}$ i $1900 \mathrm{MHz}$. Osnovne prednosti ove tehnologije ogledaju se u mogućnostima ostvarivanja međunarodnog saobraćaja, visokom kvalitetu prenosa govornog signala, većoj sigurnosti prenosa informacija, kao i mogućnostima koje ovaj standard otvara kada je u pitanju implementacija različitih drugih servisa [4].

Danas je na tržištu moguće pronaći različite GSM/ GPRS modeme koji nude različite mogućnosti povezivanja kao i različite načine komunikacije i slanja podataka. Uzimajući u obzir limitirane mogućnosti napajanja, način povezivanja kao i rad u otvorenim uslovima meteorološke stanice jedno od rešenja koje se izvojilo jeste SIM900-TTL UART GSM/GPRS model kompanije Rhydo Technologies (P) Ltd². Pomenuti GPS/GPRS TTL UART modem je zasnovan na Quad-band GSM/ GPRS enginu u oznaci SIM900A. Ovaj engine radi na sledećim frekvencijama: $850 \mathrm{MHz}, 900 \mathrm{MHz}, 1800 \mathrm{MHz}$ i $1900 \mathrm{MHz}$. Veoma je kompaktan u pogledu veličine kao i korišćenja u sklopu GSM modema. Ovaj modem je dizajniran za rad u okviru 3.3V/5V TTL kola, što mu omogućava direkno povezivanje kako sa mikrokontrolerima koji rade na $3.3 \mathrm{~V}$ tako i sa mikrokontrolerima koji rade na 5V [5]. Povezivanje na izvor napajanja može se ostvariti u opsegu od 5V-12V. Propusni opseg može se podešavati u opsegu od $9600 \mathrm{~kb} / \mathrm{s}$ do $115200 \mathrm{~kb} / \mathrm{s}$. Sami propusni opseg podešava se pomoću AT komandi. Inicijalno modem je podešen na propusni opseg od 9600 $\mathrm{kb} / \mathrm{s}$. Povezivanje modema sa mikrokontrolerom zasnovano je na dva provodnika (Tx, $\mathrm{Rx})$ za komunikaciju i jedan provodnik za napajanje [6]. Ovaj GSM/GPRS TTL modem ima interni TCP/IP stek koji omogućava uspostavljanje internet konekcije putem GPRS-a. Pogodan je kako za slanje SMS poruka tako i za korišćenje od strane aplikacija za slanje paketa podataka putem TCP/IP, kao što je slučaj sa meteorološkim stanicom.

2 Rhydo Technologies (P) Ltd, http://www.rhydolabz.com/ 
Kako bi se obavilo poređenje performansi pomenuta dva komunikaciona modula unapred su definisani kriterijumi poređenja koji su u direktnoj vezi sa potrebama realizacije komunikacije meteorološke stanice sa baznom stanicom. Parametri koji su uzeti u obzir prilikom poređenja jesu: način povezivanja modula, potrošnja električne enegije, maksimalna moguća razdaljina između meteorološke stanice i bazne stanice u pogledu prenosa signala, brzina prenosa podataka.

Celokupno poređenje ZigBee XBee S2C 802.15.4 radio frekventnog modula sa SIM900 GSM/GPRS modulom bazirano na nabrojanim parametrima pokazalo je da je SIM900 GSM/GPRS modul bolje rešenje za realizaciju komunikacije u sistemu meteorološka stanica bazna stanica. Bežični telekomunikacioni sistem zasnovan na korišćenju ovog modula omogućava veću mobilnost same meteorološke stanice, nezavisnost komunikacije od međusobne udaljenosti meteorološke i bazne stanice, kao i veću brzinu prenosa podataka. Veća potrošnja energije ovog modula u odnosu sa odabrani RF modul zanemarljiva je činjenica spram svih navedenih prednosti.

\section{ZAKLJUČAK}

Primena meteorološke stanice u okviru poljoprivredne proizvodnje pokazuje višestruke prednosti. Prednosti primene ogledaju se kako u domenu praćenja promena meteoroloških parametara i donošenju odluka o dnevnim aktivnostima na poljoprivrednim proizvodnim površinama tako i u domenu kreiranja velikih skupova meteorloških i prostorno vemenskih podata. Kreiranjem velikih skupova podataka omogućava se njihova buduća analiza, čime se dobijaju šabloni među podacima pogodni za korišćenje u procesu predikcije i donošenja odluka.

Realizacija meteorološke stanice bazirane na jednostavnom skupu komponenti dostupnih na tržištu prikazana u ovom radu odlikuje je niskom cenom realizacije. Pritom niska cena realizacije nije uticala na kvalitet komponenti, njihovu preciznost i mogućnost rada u spoljašnjim uslovima.
U velikom broju slučajeva proizvodne poljoprivredne površini nemaju konstantan izvor napajanja, pa je samim tim jedan od problema u realizaciji meteorološke stanice namenjene upotrebi u poljoprivredi i napajanje iste. Jedna od ideja za budići rad upravo je realizacija napanja putem fotonaponskog panela. Nastavak ovog istraživanja pored realizacije napajanja putem fotonaponskog panela ogleda se i u realizaciji softverskog rešenja koje bi obuhvatalo prijem paketa podataka sa meteorološke stanice i njihovu dalju obradu.

\section{ZAHVALNOST}

Ovaj rad je podržan od strane Ministarstva prosvete, nauke i tehnološkog razvoja, Vlade Republike Srbije u okviru projekta TR 32023 i TR 35026

\section{LITERATURA}

[1] K. Krishnamurthi, S. Thapa, L. Kothari, and A. Prakash, "Arduino Based Weather Monitoring System," Int. J. Eng. Res. Gen. Sci., vol. 3, no. 2, pp. 452-458, 2015.

[2] M. Ilić, P. Spalević, and M. Veinović, "Predlog modela sistema za predikciju pojave jutarnjih mrazeva," Zbornik radova 60. konferencije za elektroniku, telekomunikacije, računarstvo, automatiku i nuklearnu tehniku ETRAN, 2016, p. RT3.6 1-6.

[3] D. Gislason, Zigbee Wireless Networking. 30 Corporate Drive, Suite 400, Burlington, MA 01803, USA: Newnes - Elsevier, 2008.

[4] M. Stojčev, "Celularne bežične mreže," in Računarske mreže i prenos podataka, Osnovni ud., Niš: Elektronski fakultet Niš, 2005, pp. 268-295

[5] S. SIMCom, "TCPIP Application Note." Shanghai SIMCom Wireless Solutions Ltd, pp. 1-28, 2010.

[6] R. Technologies, "SIM 900 - TTL UART GSM/ GPRS Modem." Rhydo Technologies (P) Ltd, Golden Plaza, Chitoor Road, Cochin - 682018, Kerala State, India, pp. 1-21, 2011 